\title{
PREVALENSI GANGGUAN FUNGSI KOGNITIF DAN DEPRESI PADA \\ PASIEN STROKE DI IRINA F BLU RSUP \\ PROF. DR. R. D. KANDOU MANADO
}

\author{
${ }^{1}$ Indha Wardhani P.L. Hasra \\ ${ }^{2}$ Herdy Munayang \\ ${ }^{2}$ L.F.J.Kandou
}

\author{
${ }^{1}$ Kandidat Skripsi Fakultas Kedokteran Universitas Sam Ratulangi Manado \\ ${ }^{2}$ Bagian Psikiatri Fakultas Kedokteran Universitas Sam Ratulangi Manado \\ Email: iin hasra@yahoo.com
}

\begin{abstract}
Abstrak: Stroke is a clinical syndrome caused by blood circulatory disorders from one part of the brain that creates a functional disorder of the brain like neurological deficits and nerve paralysis. Depression and cognitive impairment is a results of the occurence of stroke. This study aimed to reveal the prevalence of cognitive impairment and depression in stroke patients in the neurology inpatient room F Prof. DR. R. D. Kandou Hospital Manado. This was a descriptive study with a crosssectional design. The sample is all stroke patient in neurology inpatient room F Prof. DR. R. D. Kandou Hospital Manado who fulfilled the inclusion criteria. The results showed that $32.4 \%$ respondents are without cognitive impairment and $67.5 \%$ with cognitive impairment. Of the cognitive impairment group there were $27 \%$ mild cognitive impairment, $40.5 \%$ moderate cognitive impairment and there was no patient with severe cognitive impairment. The results of depression status examination showed $24.3 \%$ without depression and $75.7 \%$ with depression. Of the depression group there were 59.5\% mild depression, $10.8 \%$ moderate depression, and $5.4 \%$ severe depression. The study showed that 18 participants had cognitive impairment and depression.
\end{abstract}

Conclusion: From 37 respondents, there were 7 respondents (19\%) had only cognitive impaiment, 10 respondents (27\%) had only depression and 18 respondents (49\%) with cognitive impaiment and depression.

Keywords : cognitive impairment, depression, stroke

Abstrak: Stroke adalah suatu sindrom yang disebabkan oleh adanya gangguan aliran darah pada salah satu bagian otak yang menimbulkan gangguan fungsional otak berupa defisit neurologik atau kelumpuhan saraf. Depresi dan gangguan kognitif adalah salah satu akibat dari terjadinya stroke. Penelitian ini bertujuan untuk mengetahui prevalensi gangguan fungsi kognitif dan depresi pada pasien stroke di Irina F Neuro BLU RSUP Prof. DR. R. D. Kandou Manado Penelitian ini menggunakan jenis penelitian "observasional” dengan desain "studi cross sectional”. Sampel penelitian adalah seluruh pasien stroke di Irina F Neuro BLU RSUP Prof. DR. R. D. Kandou Manado 
yang memenuhi kriteria inklusi. Hasil pemeriksaan fungsi kognitif didapatkan 32,4 \% normal, sedangkan yang mengalami gangguan fungsi kognitif 67,5 \% dimana gangguan kognitif ringan $27 \%$, gangguan kognitif sedang 40,5 \% dan tidak ada gangguan kognitif berat. Hasil pemeriksaan status depresi didapatkan 24,3 \% normal, sedangkan yang mengalami depresi 75,7 \% dimana depresi ringan 59,5 \%, depresi sedang 10,8 \%, dan depresi berat 5,4 \%. Dari hasil pemeriksaan didapatkan 18 orang dengan gangguan fungsi kognitif yang disertai dengan depresi.

Kesimpulan: Dari 37 responden, didapatkan 7 orang (19\%) yang hanya mengalami gangguan fungsi kognitif, 10 orang (27\%) yang hanya mengalami depresi dan 18 orang (49\%) dengan gangguan fungsi kognitif dan depresi.

Keyword : gangguan fungsi kognitif, depresi, stroke

\section{PENDAHULUAN}

Stroke yang juga dikenal dengan istilah Gangguan Peredaran Darah Otak (GPDO), merupakan suatu sindrom yang disebabkan oleh adanya gangguan aliran darah pada salah satu bagian otak yang menimbulkan gangguan fungsional otak berupa defisit neurologik atau kelumpuhan saraf. ${ }^{1}$

Menurut American Heart Association (AHA), angka kematian penderita stroke di Amerika setiap tahunnya adalah 50 - 100 dari 10.000 orang penderita. ${ }^{1}$ Menurut Yayasan Stroke Indonesia terdapat kecenderungan meningkatnya jumlah penyandang stroke di Indonesia dalam dasawarsa terakhir. ${ }^{2}$

Depresi merupakan sindrom neuropsikiatri yang umum terjadi pasca stroke. Terjadi pada 30-50 \% pasien stroke dalam waktu 2 tahun dari kejadian awal. ${ }^{3}$

Salah satu akibat dari terjadinya stroke adalah gangguan fungsi kognitif. Insiden gangguan fungsi kognitif meningkat tiga kali lipat setelah stroke, dan biasanya melibatkan kemampuan visuospasial, memori, orientasi, bahasa, perhatian, dan fungsi eksekutif. ${ }^{4}$
Fungsi kognitif adalah kemampuan berpikir dan memberikan rasional, termasuk proses belajar, mengingat menilai, orientasi, persepsi dan memperhatikan. ${ }^{5}$ Gangguan fungsi kognitif merupakan gangguan fungsi luhur otak berupa orientasi, perhatian, kosentrasi, daya ingat dan bahasa serta fungsi intelektual yang diperlihatkan dengan adanya gangguan dalam berhitung, bahasa, daya ingat semantik (kata-kata) dan pemecahan masalah. Gangguan fungsi kognitif erat kaitannya dengan fungsi otak karena kemampuan untuk berpikir akan dipengaruhi oleh otak. ${ }^{6}$

Depresi merupakan gangguan mood berupa kesedihan intens, yang berlangsung dalam waktu lama, dan menggangu kehidupan normal yang insidennya semakin meningkat seiring dengan meningkatnya tekanan hidup. ${ }^{7}$ Etiologi depresi terdiri dari faktor biologi: neurotropin, miRNA, stress hormon, teori inflamasi, teori microbiota usus dan neurogenesis dewasa, faktor genetik dan faktor psikososial. ${ }^{8,9,10}$

\section{METODE PENELITIAN}


Jenis penelitian yang digunakan dalam penelitian ini adalah dengan penelitian dekskriptif dengan pendekatan potong lintang. Penelitian ini dilakukan di Irina F Neurologi BLU RSUP Prof. DR. R. D. Kandou yang dilaksanakan pada bulan November-Desember 2014. Populasi adalah seluruh pasien di Irina F Neurologi BLU RSUP Prof. DR. R. D. Kandou yang dirawat selama bulan November-Desember 2014 dan sampel adalah pasien yang memenuhi kriteria inklusi yaitu : Pasien stroke yang dirawat di Irina $\mathrm{F}$ Neurologi BLU RSUP Prof. DR. R. D. Kandou Manado, mampu berkomunikasi dengan baik, dan bersedia untuk menjadi responden dan kriteria ekslusi : mengalami afasia motorik, sensorik maupun global dan mengalami hemiparesa dupleks. Variabel penelitian dalah fungsi kognitif dan depresi.

Pengambilan data diperoleh dari kuisioner Mini Mental State Examination dan Hamilton Depresson Rating Scale.

\section{HASIL PENELITIAN}

Penelitian dilakukan pada pasien stroke yang dirawat di Irina F Neurologi BLU RSUP Prof DR RD Kandou pada bulan NovemberDesember 2013, didapatkan jumlah sampel 37 orang.

\section{Tabel 1. Distribusi berdasarkan umur}

\begin{tabular}{lll}
\hline $\begin{array}{l}\text { Umur } \\
\text { tahun) }\end{array}$ & $\begin{array}{l}\text { Frekuensi } \\
(\mathrm{n})\end{array}$ & Persen(\%) \\
\hline $31-45$ & 4 & 10,8 \\
\hline $46-60$ & 20 & 54,1 \\
\hline $61-75$ & 12 & 32,4 \\
\hline$>75$ & 1 & 2,7 \\
\hline Total & 37 & 100 \\
\hline
\end{tabular}

Tabel 1 menunjukkan responden bahwa terdapat umur 31-45 tahun sebanyak 4 responden (10,8 \%), umur 46-60 tahun 20 responden (54,1\%), umur 61-75 sebanyak 12 responden $(32,4 \%)$ dan umur $>75$ tahun sebanyak 1 orang.

Tabel 2. Distribusi berdasarkan jenis kelamin

Jenis $\quad$ Frekuensi $\quad$ Persen

kelamin

\begin{tabular}{lll}
\hline Laki-laki & 14 & 37,8 \\
\hline Perempuan & 23 & 62,2 \\
\hline Total & 37 & 100
\end{tabular}

Tabel 2 menunjukkan sampel lebih banyak perempuan daripada laki-laki, yaitu laki-laki 14 orang (37,8 \%) sedangkan perempuan 23 orang (62,2 \%).

Tabel 3. Distribusi berdasarkan status pernikahan

\begin{tabular}{lll}
\hline $\begin{array}{l}\text { Status } \\
\text { pernikahan }\end{array}$ & Frekuensi & Persen \\
\hline Menikah & 27 & 73 \\
\hline Cerai mati & 8 & 21,6 \\
\hline Cerai hidup & 2 & 5,4 \\
\hline Total & 37 & 100
\end{tabular}

Tabel 3 menunjukkan responden yang menikah 27 orang (73\%), cerai mati sebanyak 8 orang (21,6 \%) dan cerai hidup 2 orang (5,4 $\%)$.

Tabel 4. Distribusi berdasarkan pendidikan

\begin{tabular}{lll}
\hline Pendidikan & Frekuensi & Persen \\
\hline SD & 18 & 48,6 \\
\hline SMP & 11 & 29,7 \\
\hline SMA & 7 & 18,9 \\
\hline S1 & 1 & 2,7 \\
\hline Total & 37 & 100 \\
\hline
\end{tabular}


Tabel 4 menunjukkan data responden berdasarkan pendidikan yaitu 18 orang (48,6 \%) dengan pendidikan SD, 11 orang (29,7 \%) dengan pendidikan SMP, 7 orang (18,9 \%) dengan pendidikan SMA dan hanya 1 orang (2,7 \%) dengan pendidikan S1.

Tabel 5. Distribusi berdasarkan pekerjaan

\begin{tabular}{lll}
\hline Pekerjaan & Frekuensi & Persen \\
\hline PNS & 3 & 8,1 \\
\hline Karyawan & 5 & 13,5 \\
\hline Wiraswasta & 8 & 21,6 \\
\hline Petani & 4 & 10,8 \\
\hline IRT & 17 & 45,9 \\
\hline Total & 37 & 100 \\
\hline
\end{tabular}

Tabel 5 menunjukkan responden dengan pekerjaan PNS sebanyak 3 orang (8,1 \%), karyawan 5 orang (13,5 \%), wiraswasta 8 orang (21,6 \%), petani 4 orang (10,8 \%) dan IRT sebanyak 17 orang (45,9 \%).

Tabel 6. Distribusi berdasarkan jenis stroke

\begin{tabular}{lll}
\hline Jenis Stroke & Frekuensi & Persen \\
\hline Stroke Iskemik & 20 & 54,1 \\
\hline Stroke & 17 & 45,9 \\
Hemoragik & & \\
\hline Total & 37 & 100
\end{tabular}

Tabel 6 menunjukkan responden sebanyak 20 orang (54,1\%) dengan stroke iskemik sedangkan 17 orang (45,9 \%) dengan stroke hemoragik.

Tabel 7. Hasil Pemeriksaan MMSE

\begin{tabular}{lll}
\hline Hasil & Frekuensi & Persen(\%) \\
Pemeriksaan & (n) & \\
& & \\
\hline Normal & 12 & 32,4 \\
\hline Ringan & 10 & 27 \\
\hline
\end{tabular}

\begin{tabular}{lll}
\hline Sedang & 15 & 40,5 \\
\hline Berat & 0 & 0 \\
\hline
\end{tabular}

Tabel 7 menunjukkan asil pemeriksaan dengan MMSE menunjukkan, terdapat 12 orang $(32,4 \%)$ yang tidak mengalami gangguan fungsi kognitif, sebanyak 10 orang (27\%) yang mengalami gangguan fungsi kognitif ringan, sebanyak 15 orang $(40,5 \%)$ yang mengalami gangguan fungsi kognitif sedang sedangkan reponden dengan gangguan kognitif berat tidak ditemukan.

\section{Tabel 8. Hasil Pemeriksaan Skala Depresi}

Hasil Frekuensi Persen

Pemeriksaan

\begin{tabular}{|c|c|c|}
\hline Normal & 9 & 24,3 \\
\hline Ringan & 22 & 59,5 \\
\hline Sedang & 4 & 10,8 \\
\hline Berat & 2 & 5,4 \\
\hline
\end{tabular}
pemeriksaan HDRS menunjukkan bahwa, sebanyak 9 orang (24,3\%) tidak mengalami depresi, sebanyak 22 orang (59,5\%) yang mengalami depresi ringan, sebanyak 4 orang $(10,8 \%)$ yang mengalami depresi sedang dan yang mengalami depresi berat terdapat 2 orang $(5,4 \%)$.

Tabel 9. Kejadian Gangguan Fungsi Kognitif disertai Depresi

\begin{tabular}{ccc}
\hline Fungsi & \multicolumn{2}{c}{ Status Depresi } \\
\cline { 2 - 3 } Kognitif & Tanpa & Depresi \\
& Depresi & \\
\hline Tanpa & & \\
Gangguan & & 10 \\
Fungsi & 2 & 10 \\
\hline
\end{tabular}




\begin{tabular}{ccc}
\hline Kognitif & & \\
\hline Gangguan & & 18 \\
Fungsi & 7 & \\
Kognitif & & \\
\hline
\end{tabular}

Tabel 9 menunjukkan berdasarkan

hasil penelitian didapatkan 18 orang yang mengalami gangguan fungsi kognitif disertai dengan depresi.

\section{BAHASAN}

Penelitian ini dilakukan pada pasien stroke yang di rawat di Irina F Neurologi BLU RSUP Prof. DR. R. Kandou Manado selama bulan November-Desember 2013. Diperoleh 37 orang pasien yang memenuhi kriteria inklusi dan ekslusi.

$$
\text { Berdasarkan hasil penelitian }
$$
didapatkan 18 orang yang menderita gangguan fungsi kognitif yang juga mengalami depresi. Seperti penelitian yang dilakukan oleh Congstate, terdapat peningkatan gangguan fungsi kognitif pada pasien dengan depresi dan gangguan fungsi kognitif tersebut sangat berpengaruh terhadap kemampuan fungsional pasien. $^{11}$

Berdasarkan pada hasil penelitian didapatkan bahwa sebagian besar pasien stroke mengalami gangguan fungsi kognitif yakni 25 orang $(67,5 \%)$ dan sebagian besar mengalami gangguan fungsi kognitif pada tingkatan sedang yakni 15 orang (40,5\%). Pada penelitian ini tidak didapatkan pasien dengan gangguan kognitif berat karena sesuai dengan kriteria inklusi dimana pasien harus dengan kesadaran penuh. Berdasarkan medical corporation center, penyakit serebrovaskuler seperti stroke merupakan penyebab kedua terjadinya gangguan fungsi kognitif. ${ }^{12}$ Penyakit serebrovaskular adalah penyakit yang menyebabkan pembuluh darah yang menyuplai darah ke otak mengalami kematian/kerusakan sehingga terjadi defisit fungsi otak, salah satunya fungsi kognitif. ${ }^{13}$ Berdasarkan literatur yang ada, 20-30\% pasien yang terkena stroke akan mengalami gangguan fungsi kognitif. ${ }^{14}$ Penyebab utama adalah akumulasi infark-infark lakunar, lesi-lesi iskemik dan hopoperfusi serebral. Jumlah terkecil infak maupun lesi pada stroke yang bisa menyebabkan gangguan fungsi kognitif adalah lebih dari $10 \mathrm{ml}$ dan kurang dari $50 \mathrm{ml}$ yang besarnya 1 - 4\% dari volume otak. Gangguan kognitif bisa terjadi kurang dari 10 $\mathrm{ml}$ bila itu mengenai hipothalamus, thalamus, batang otak atau hipokampus. Jenis yang paling umum dari gangguan kognitif yang timbul dari stroke adalah gangguan perhatian, bahasa, masalah memori, persepsi, pembuatan keputusan, disfungsi eksekutif sehingga mempengaruhi kemampuan untuk menganalisis, menafsirkan, merencanakan, mengatur dan melaksanakan informasi yang kompleks. ${ }^{12}$

\section{Orientasi $^{2}$}

Pada penelitian terdapat 7 orang (18,9\%) yang mempunyai skor orientasi $<5$. Pasien stroke biasanya akan mengalami gangguan orientasi tempat, waktu dan orang.

\section{Memori $^{15}$}

Pada penelitian didapatkan 3 orang $(8,1 \%)$ yang mempunyai skor memori <3. Masalah memori tidak jarang terjadi pada stroke. Pasien terkadang mengalami kesulitan untuk belajar dan mengingat informasi yang baru ataupun 
mengambil memori jangka panjangnya. Masalah memori jangka pendek biasanya terjadi apabila terjadi gangguan di otak kiri sedangkan bila terjadi gangguan di otak kanan akan menyebabkan masalah memori lainnya.

\section{Perhatian dan perhitungan ${ }^{16}$}

Pada penelitian didapatkan 13 orang (35,1\%) yang mempunyai skor perhatian dan perhitungan $<4$. Masalah dengan perhatian sangat umum terjadi setelah stroke, terutama di beberapa minggu pertama. Pasien biasanya mengalami kesulitan untuk berkonsentrasi dan terkadang terlihat kebingungan menjawab pertanyaan yang diberikan. Pasien biasanya akan susah mengalami konsentrasi bila yang stroke mempengaruhi otak sebelah kanan.

\section{Mengingat kembali ${ }^{17}$}

Pada penelitian ini didapatkan 19 orang (51,4\%) yang mempunyai skor mengingat kembali $<3$. Pada pasien stroke sering terjadi masalah dalam mengingat kembali atau memanggil memori jangka panjang.

\section{Bahasa $^{18}$}

Pada penelitian ini didapatkan 9 orang (24,3\%) yang mempunyai skor bahasa $<6$. Setelah kejadian stroke, salah satu masalah yang paling umum adalah kesulitan berkomunikasi. Kesulitan komunikasi ini disebut afasia. Afasia adalah hilangnya sebagian atau total kemampuan untuk berbicara, memahami apa yang orang katakan, membaca atau menulis. Hal ini mungkin dapat mempengaruhi hanya satu aspek bahasa.

\section{Persepsi $^{16}$}

Stroke dapat mempengaruhi setiap bagian dari proses ini. Pasien biasanya mengalami kesulitan untuk mengambil informasi ditempat pertama lalu menafsirkan informasi tersebut. Hal ini disebut agnosia,dan biasanya agnosia hanya mempengaruhi salah satu indra pada pasien stroke.

\section{Fungsi eksekutif $^{15}$}

Pada pasien stroke biasanya akan mempengaruhi pasien dalam membuat keputusan. Pasien akan sulit berpikir ketika diharuskan membuat keputusan dari beberapa pilihan yang datang.

Sedangkan berdasarkan hasil penelitian pasien stroke juga sebagian besar mengalami depresi yakni 28 orang $(75,7 \%)$ walaupun yang paling banyak depresi ringan. Menurut studi dari American Stroke Assosiation, depresi adalah perubahan emosional yang paling umum terjadi setelah stroke. ${ }^{15}$ Hampir $79 \%$ pasien stroke mengalami depresi baik di awal maupun akhir setelah stroke. Keparahan depresi pada pasien stroke ditentukan oleh beberapa faktor antara lain dari lokasi lesi di otak, adanya riwayat keluarga yang mengalami depresi dan fungsi sosial sebelum stroke. Para pasien biasanya merasa sedih dan murung dengan penyakit yang dideritanya, yang mengakibatkan pasien sulit melakukan kegiatan sehari-hari namun jarang yang sampai pada tahap ingin bunuh diri. Tingkat depresi juga sangat dipengaruhi oleh derajat kecacatan atau ketidakmampuan dari pasien. Perasaan tidak berdaya, tidak bisa bekerja, selalu merasa lemah dan tidak berenergi juga ketergantungan pada orang lain dalam kehidupan sehari-hari paling sering menyebabkan pasien mengalami depresi. Insomnia maupun hipersomnia juga paling sering dikeluhkan oleh pasien stroke dengan 
depresi selain gejala kecemasan somatik, gangguan gastrointestinal, gangguan gairah seksual maupun penurunan berat badan hingga 5\%. Depresi pada pasien stroke biasanya kurang diperhatikan oleh tenaga kesehatan dan juga tidak disadari oleh pasien sendiri. Pengobatan depresi sangat mempengaruhi pengobatan pada pasien stroke dengan meningkatkan status medisnya, kualitas hidupnya, dan mengurangi rasa ketidakberdayaan.

\section{SIMPULAN DAN SARAN}

Hasil pemeriksaan fungsi kognitif didapatkan $32,4 \%$ normal, sedangkan yang mengalami gangguan fungsi kognitif $67,5 \%$ dimana gangguan kognitif ringan $27 \%$, gangguan kognitif sedang 40,5 \% dan tidak ada gangguan kognitif berat. Hasil pemeriksaan status depresi didapatkan 24,3 \% normal, sedangkan yang mengalami depresi 75,7 \% dimana depresi ringan 59,5\%, depresi sedang 10,8 \%, dan depresi berat 5,4 \%. Dari hasil pemeriksaan didapatkan 18 orang dengan gangguan fungsi kognitif yang disertai dengan depresi.

Perlunya tenaga kesehatan untuk memperhatikan perbaikan fungsi kognitif dari pasien stroke. Perlunya tenaga kesehatan lebih memperhatikan status depresi pada pasien stroke yang sangat mempengaruhi pengobatan stroke itu sendiri. Perlunya dilakukan penelitian lebih lanjut tentang hubungan gangguan fungsi kognitif dengan kejadian depresi pada pasien stroke ataupun sebaliknya.
Perlunya dilakukan penelitian lebih lanjut tentang hubungan gangguan fungsi kognitif dengan kemampuan fungsional pasien.

\section{DAFTAR PUSTAKA}

1. Dinata CA, Safrita Y, Sastri S. Gambaran Faktor Risiko dan Tipe Stroke pada Pasien Rawat Inap di Bagian Penyakit Dalam RSUD Kabupaten Solok Selatan Periode 1 Januari 2010 - 31 Juni 2012. Jurnal Kesehatan Andalas. Padang:FK UNAND.2013

2. Yastroki. Pengetahuan Sekilas Tentang Stroke. 2012. Available from : http://www.ystroki.or.id/read.php/id=340 [diakses pada 25 September 2013].

3. Cummings JL, Trimble MR. [Concise Guide to Neuropsychiatry and Behavioral Neurology]. Washington DC: American Psychiatric Press

4. Paparang TN, Mahama CN, Ngantung DJ. Gambaran Fungsi Kognitif pada Pasien Rawat Jalan dengan Riwayat Stroke di Poliklinik Sarat RSUP Prof. DR. R. D. Kandou Manado. Jurnal Biomedik, Volume 5, Nomor 1, Suplemen, Maret 2013, hlm. S141-47:FK Unsrat.2013

5. Herlina. Pengaruh Triterpen Total Pegagan Terhadap Fungsi Kognitif Belajar dan Mengingat pada Mencit Jantan Albino. Palembang:FMIPA Universitas Sriwijaya.2010

6. Lisnaini. Senam Vitalisasi Otak Dapat Meningkatkan Fungsi Kognitif Usia Dewasa Muda. Jakarta:Fisioterapi Universitas Kristen Indonesia.2012 
7. Radityo WE. Depresi dan Gangguan Tidur. Jurnal Medika Udayana. Denpasar:FK UNUD.2012

8. Rosa Villanueva. Neurobiology of Major Depression Disorder. Neural Plasticity, Volume 2013, Article ID 873278. Madrid:Hindawi Publishing Corporation.2013

9. Craighead WE, Miklowitz DJ, Craighead WE. Psychopathology: History, Diagnosis and Empirical Foundations. New Jersey:John Wiley \& Sons, Inc. 2007

10. Gregor Hasler. Pathophysiology of Depression: Do We Have Any Solid Evidence of Interest to Clinicans. World Psychiatry;9;155-161.

Switzerland:Psychiatric University Hospital, University of Berne.2010

11. Congstate. Cognitive Dysfunction Also Present in Patients With Depression. 2012. Available from www.congstate.com/cognitivedysfunction-also-present-in-patients-wiyhdepression/\#.Us9thywgGK2 [diakses pada 9 januari 2014]

12. Anonim. Stroke and Cognitive Impairment. Available from : www.mccare.com [diakses pada 6 januari 2014]

13. Alzheimer Australia. Vascular Cognitive Impairment. 2012. Available from : www.fightdementia.org.au [ diakses pada 6 januari 2014].

14.Kalbe Medical. Citicoline Jangka Panjang Memperbaiki Ganggua Kognitif Vaskuler Pasca-Stroke. Jakarta:Kalbe Medical Portal
15. American Stroke Assosiation. Cognitive Challenges After Stroke. 2013. Available from

www.strokeassosiation.org/STROKEORG /LifeAfterStroke/RegainingIndependence/ EmotionalBehavioralChallenges/Cognitive -Challenges-After-

Stroke UCM 309904 Article.jsp [diakses pada 6 januari 2014]

16. Stroke Assosiation. Cognitive Problem After Stroke. 2012. Available from : www.stroke.org.uk/factsheet/cognitiveproblems-after-stroke [diakses pada 6 januari 2014].

17. Stroke Rehab. Cognitive Impairment. 2012. Available from : www.strokerehab.com/cognitive-impairment.html [diakses pada 6 januari 2014].

18. Anonim. Recovery After Stroke : Thinking and Cognition. Available from : www.stroke.org/site/DocServer/NSAFactS heet_Cognition.pdf?docID=986 [diakses pada 6 januari 2014] 